\title{
MENINGKATKAN HASIL BELAJAR IPA MELALUI MODEL GROUP INVESTIGATION BERBANTUAN VIDEO PADA SISWA SEKOLAH DASAR
}

\author{
Angelique Rabeka Lasfeto ${ }^{1, *}$ \\ 1 Jurusan Pendidikan Guru Sekolah Dasar, Universitas Pendidikan Ganesha
}

\begin{abstract}
Abstrak
This study aims to determine the improvement of student learning outcomes through video-assisted group investigation model. This type of research is a classroom action research with the subject of research is the students of grade V SD N 4 Kaliuntu as many as 38 people. Data collection in this research is done by test method in the form of multiple choice. The data that have been obtained is then analyzed using quantitative descriptive statistical analysis method. The results of this study indicate that in the first cycle the average learning outcome of IPA of 70.02 has increased by 10.5 in cycle II to 80.07. While for the students' completeness score in the first cycle of $76.31 \%$ of the students who numbered 38 people only thoroughly for 29 people. And the increase in cycle II of $7.89 \%$ to $84.21 \%$ and students experiencing completeness in learning as many as 32 people from 38 people. The results of this study indicate that student learning outcomes can be increased through the videoassisted group investigation model
\end{abstract}

Kata Kunci:

Video-assisted group investigation model, learning outcomes

\section{PENDAHULUAN}

Pendidikan merupakan sumber kemajuan bangsa yang sangat menentukan daya saing bangsa. Dalam Undang-undang Sistem Pendidikan Nasional Nomor 20 Tahun 2003 pasal 3 disebutkan bahwa Pendidikan nasional berfungsi untuk mengembangkan kemampuan dan membentuk watak serta peradaban bangsa yang bermartabat dalam rangka mencerdaskan kehidupan bangsa, bertujuan untuk berkembangnya potensi peserta didik agar menjadi manusia yang beriman dan bertakwa kepada Tuhan Yang Maha Esa, berakhlak mulia, sehat, berilmu, cakap, kreatif, mandiri, dan menjadi warga negara yang demokratis serta bertanggung jawab. Peningkatan mutu pembelajaran sangat perlu dilakukan guna meningkatkan kompetensi peserta didik sebagai calon sumber daya manusia yang berkualitas, terutama pembelajaran di Sekolah Dasar, karena pendidikan di Sekolah Dasar merupakan jenjang pendidikan dasar yang berfungsi sebagai peletakan dasar-dasar keilmuan dan membantu mengoptimalkan perkembangan siswa melalui pembelajaran yang dibimbing oleh guru.

Berdasarkan Standar Kompetensi dan Kompetensi Dasar Tingkat SD/MI dalam Peraturan Menteri Pendidikan Nasional Nomor 22 Tahun 2006 tentang Standar Isi untuk satuan pendidikan dasar dan menengah bahwa pendidikan IPA diharapkan dapat menjadi wahana bagi peserta didik untuk mempelajari diri sendiri dan alam sekitar, serta prospek pengembangan lebih lanjut dalam menerapkannya di dalam kehidupan sehari-hari. Proses pembelajarannya menekankan pada pemberian pengalaman langsung untuk mengembangkan kompetensi agar menjelajahi dan memahami alam sekitar secara ilmiah.

Dalam SD pun IPA juga mempelajari seluruh aktifitas yang ada di alam. Hal ini tercantum dalam standar isi bahwa ruang lingkup IPA di SD meliputi aspek-aspek berikut: 1) makhluk hidup dan proses kehidupan, yaitu manusia, hewan, tumbuhan dan interaksinya dengan lingkungan, serta kesehatan, 2) benda/materi, sifat-sifat dan kegunaannya meliputi cair padat dan gas, 3) energi dan perubahannya meliputi gaya, bunyi, panas, magnet, listrik, cahaya, dan pesawat sederhana, 4) bumi dan alam semesta meliputi tanah, bumi, tata surya, dan benda-benda langit lainnya. Dalam mempelajari IPA, tidak hanya memberikan materi-materi yang termasuk di dalamnya melainkan memberikan kesempatan kepada peserta didik untuk berbuat, berpikir, dan bertindak untuk mengetahui pengetahuan itu sendiri. Hal ini sama seperti yang dijelaskan oleh Rustaman (2011:1.5)

* Corresponding author.

E-mail Addresses: rebeccaangelique23@gmail.com (angelique rabeka lasfeto) 
bahwa IPA terdiri dari fakta, konsep, prinsip, hukum, dan teori yang dapat dicapai melalui penggunaan proses sains, yaitu melalui metode-metode sains atau metode-metode ilmiah (scientific methods), bekerja ilmiah (scientific inquiry).

IPA merupakan salah satu mata pelajaran utama di SD/MI. Dalam Standar Isi (2006) dijelaskan bahwa pembelajaran IPA sebaiknya dilaksanakan secara inkuiri ilmiah (scientific inquiry) untuk menumbuhkan kemampuan berpikir, bekerja dan bersikap ilmiah serta mengkomunikasikannya sebagai aspek penting kecakapan hidup. Oleh karena itu pembelajaran IPA di SD/MI menekankan pada pemberian pengalaman belajar secara langsung melalui penggunaan dan pengembangan keterampilan proses dan sikap ilmiah. Namun dalam kenyataannya anak usia SD kemampuan berfikirnya masih rendah, hal ini berpengaruh keberhasilan anak dalam mengikuti pembelajaran IPA. Jika guru kurang inovatif dan kreatif dalam memberikan pelajaran maka anak tidak akan memahami pembelajaran dan hasil belajarnya pun rendah. Berdasarkan wawancara dengan beberapa siswa kelas V, diketahui bahwa dalam pembelajaran IPA guru belum menggunakan model pembelajaran yang sesuai dengan materi pembelajaran dan penggunaan media yang kurang sehingga masih banyak siswa yang belum memahami materi pembelajaran yang mengakibatkan hasil belajar siswa rendah.

Berdasarkan observasi mendalam yang telah dilakukan peneliti di SD N 4 Kaliuntu terungkap bahwa hasil belajar mata pelajaran IPA rendah ditunjukkan dengan 8 dari 38 siswa $(21,05 \%)$ mendapat nilai di bawah KKM (Kriteria Ketuntasan Minimal) yaitu 65. Hal ini dikarenakan keterampilan guru dan aktivitas siswa yang kurang, sehingga berdampak pada hasil belajar siswa rendah. Guru belum menggunakan model pembelajaran yang inovatif dan cenderung menggunakan metode ceramah sehingga kurang menarik minat siswa. Selama pembelajaran, guru juga kurang memaksimalkan penggunaan media sehingga kurang dapat memotivasi siswa dalam pembelajaran. Selain itu aktivitas yang dilakukan siswa kurang, terlihat selama pembelajaran hanya 11 dari 38 siswa $(28,94 \%)$ yang mengacungkan tangan untuk bertanya dan dalam menyampaikan pendapat, hanya 22 dari 38 siswa. (57,89\%). Dalam mengerjakan tugas yang diberikan guru, siswa belum melakukan perencanaan kegiatan, siswa hanya mencontek pekerjaan temannya tanpa memiliki tanggung jawab. Dalam menyusun laporan kegiatan kelompok, siswa hanya menulis sekedarnya saja tanpa melakukan penyelidikan dari berbagai sumber.

Berdasarkan masalah tersebut, maka peneliti merasa perlu memberikan suatu solusi. Solusi yang dilakukan yaitu dengan menggunakan model pembelajaran inovatif Group Investigation.Peneliti menggunakan model pembelajaran Group Investigation dengan alasan, dalam model pembelajaran Group Investigation ini siswa terlibat dalam perencanaan baik topik yang dipelajari dan bagaimana jalannya penyelidikan mereka (Trianto, 2011:78). Selanjutnya, menurut Beti (2012) keunggulan model pembelajaran Group Investigation antara lain pembelajaran yang dilakukan membuat suasana saling bekerjasama, berinteraksi, berkomunikasi antar siswa dalam kelompok dan mengemukakan pendapatnya, serta memotivasi dan mendorong siswa agar aktif dalam proses belajar mulai dari tahap pertama sampai tahap akhir pembelajaran.

Dalam penerapannya, model pembelajaran Group Investigation akan dipadukan dengan media video untuk mengeksplorasi kemampuan berpikir siswa. Selain itu video juga akan menentukan apa saja topik-topik yang akan digunakan oleh kelompok untuk diselidiki. Video pembelajaran ini memiliki kelebihan antara lain untuk menggambarkan gerakan, keterkaitan, dan memberikan dampak terhadap topik yang dibahas (Prastowo, 2012:303). Model pembelajaran Group Investigation atau Investigasi Kelompok ini berasal dari tulisan-tulisan filsafat, etika, dan psikologi. Orang pertama yang merintis menggunakan model ini adalah John Dewey. Dewey memandang bahwa kerja sama dalam kelas sebagai prasyarat unruk mengatasi berbagai persoalan kehidupan yang kompleks dan demokrasi. Kelas merupakan bentuk kerja sama dimana guru dan siswa membangun proses pembelajaran dengan perencanaan yang baik berdasarkan berbagai pengalaman, kapasitas, dan kebutuhan mereka masing-masing (Asma, 2006:61).

Dalam model pembelajaran ini, siswa harus benar-benar terlibat dalam kelompoknya untuk menyelidiki sebuah permasalahn bersama-sama. Hamdani (2011:90), menjelaskan bahwa metode pembelajaran ini melibatkan siswa sejak perencanaan, baik dalam menentukan topik maupun cara untuk mempelajarinya melalui investigasi. Metode ini menuntut siswa untuk memiliki kemampuan yang baik dalam berkomunikasi maupun keterampilan proses kelompok (group process skill).

Trianto (2011:79) menyebutkan, bahwa model ini mengajarkan siswa keterampilan komunikasi dan proses kelompok yang baik. Dalam implementasi model pembelajaran Group Investigation ini, guru membagi kelas menjadi kelompok-kelompok dengan anggota 5-6 siswa yang heterogen. Kelompok di sini dapat dibentuk dengan mempertimbangkan keakraban persahabatan atau minat yang sama dalam topik tertentu. Selanjutnya siswa memilih topik untuk diselidiki, dan 
melakukan penyelidikan yang mendalam atas topik yang dipilih. Selanjutnya ia menyiapkan dan mempresentasikan laporannya kepada seluruh kelas.

Sebagai bagian dari investigasi, para siswa mencari dan menemukan informasi dari berbagai macam sumber di dalam dan di luar kelas. Sumber ini dapat berasal dari siswa ataupun orang lain dan sumber berupa buku, internet, media cetak, media elektronik, dan sebagainya. Menurut Asma (2006:62) sumber-sumber semacam ini (buku-buku,institusi-institusi, orang-orang) memberikan banyak sekali gagasan, opini, data, solusi, atau posisi tentang persoalan yang sedang dikaji. Kemudian para siswa mengevaluasi dan mensintesiskan semua informasi yang disampaikan oleh masingmasing anggota kelompok dan akhirnya dapat menghasilkan produk berupa laporan kelompok.

Dari beberapa pendapat di atas, maka dapat disimpulkan bahwa model pembelajaran Group Investigation merupakan model pembelajaran yang menuntut adanya penyelidikan suatu topik. Model ini menuntut siswa untuk memiliki kemampuan yang baik dalam berkomunikasi maupun keterampilan proses kelompok. Awalnya siswa dibentuk kelompok secara heterogen lalu menentukan topik maupun cara untuk mempelajarinya melalui investigasi. Siswa juga bisa mencari dari beberapa sumber. Kemudian para siswa mengevaluasi dan mensintesiskan semua informasi yang disampaikan oleh masing-masing anggota kelompok dan akhirnya dapat menghasilkan produk berupa laporan kelompok.

Dalam melaksanakan model pembelajaran Group Investigation, guru berfungsi sebagai narasumber dan fasilitator. Guru berkeliling di antara kelompok-kelompok, untuk melihat apakah kelompok-kelompok itu sedang melakukan pekerjaan mereka, dan membantu mencarikan jalan keluar dari masalah-masalah yang mereka hadapi dalam interaksi kelompok dan pelaksanaan tugastugas khusus yang berkaitan dengan kegiatan pembelajaran. Dalam model pembelajaran Group Investigation, para murid bekerja melalui enam tahap. Tahap-tahap dan komponen-komponennya dijabarkan dibawah ini.

Tahap 1 : Mengidentifikasikan topik dan mengatur siswa ke dalam kelompok terdiri dari: a) Siswa meneliti beberapa sumber, mengusulkan sejumlah topik, dan mengkategorikan saran-saran,b) Siswa dikelompokkan menjadi beberapa kelompok secara heterogen, c) Siswa bergabung dengan kelompoknya untuk mempelajari topik yang telah mereka pilih, d) Guru membantu dalam pengumpulan informasi dan memfasilitasi pengaturan

Tahap 2 : Merencanakan tugas yang akan dipelajari : a) Siswa merencanakan bersama mengenai apa yang akan mereka pelajari,

Tahap 3 : Melaksanakan investigasi: a) Siswa mengumpulkan informasi, menganalisis data, dan membuat kesimpulan, b) Siswa saling bertukar, berdiskusi, mengklarifikasi, dan mensintesis semua gagasan.

Tahap 4 : Menyiapkan laporan akhir; a) Kelompok merencanakan apa yang akan mereka laporkan dan bagaimana membuat presentasi mereka.

Tahap 5 : Mempresentasikan laporan akhir: a) Presentasi dibuat untuk seluruh kelas dengan salah satu anggota kelompok untuk maju, b) Bagian presentase tersebut harus dapat melibatkan pendengarnya secara aktif.

Tahap 6 : Evaluasi: a) Siswa saling memberikan umpan balik mengenai topik tersebut, b) Guru dan siswa berkolaborasi dalam mengevaluasi pembelajaran siswa.

Dalam penelitian ini akan digunakan model pembelajaran Group Investigation dengan media video. Dengan menggunakan model ini siswa akan terlibat aktif dalam proses pembelajaran karena model ini menuntut siswa aktif dalam menyelidiki sutau persoalan dengan kelompoknya. Selain itu komunikasi dan kerja sama antara individu dalam kelompok juga perlu diperhatikan karena dengan adanya proses itu maka model pembelajaran Group Investigation akan berhasil.

Dalam penerapannya, model pembelajaran Group Investigation akan dipadukan dengan media video. Video mempunyai kelebihan memberikan pengalaman yang tak terduga kepada peserta didik serta memperlihatkan secara nyata sesuatu yang pada awalnya tidak mungkin bisa dilihat. Jadi siswa dapat menggali informasi sedalam-dalamnya dari video yang diputarkan tersebut

\section{METODE PENELITIAN}

Penelitian ini dirancang dalam bentuk penelitian tindakan kelas. Penelitian ini dirancang sampai siklus ke - N. Dalam penelitian tindakan kelas (PTK) ini mengacu pada teori yang dikemukakan Kemmis dan McTaggrat (Agung, 2005:91). Model penelitian ini terdapat empat tahapan pada satu siklus penelitian. Empat tahapan tersebut terdiridari: perencanaan, tindakan, observasi/evaluasi dan refleksi. Subjek dalam penelitian ini adalah siswa kelas V SD N 4 Kaliuntu yang berjumlah 38 orang. Variabel terikat yang menjadi fokus perhatian dalam penelitian ini yaitu hasil belajar IPA. Untuk mengumpulkan data dalam penelitian ini digunakan metode tes berupa soal pilihan ganda. 
Metode tes adalah cara memperoleh data yang berbentuk suatu tugas yang harus dikerjakan oleh seseorang atau kelompok orang yang dites. Dari tes dapat menghasilkan skor yang selanjutnya dibandingkan dengan kriteria tertentu. Metode tes merupakan suatu cara untuk mengadakan penilaian yang berbentuk suatu tugas atau serangkaian yang harus dikerjakan oleh anak atau sekelompok anak sehingga menghasilkan suatu nilai tentang tingkah laku atau prestasi anak tersebut, yang dapat dibandingkan dengan nilai yang didapat oleh anak lain atau dengan nilai standar yang ditetapkan. Tes ini diberikan pada setiap akhir pertemuan pada masing-masing siklus. Sedangkan Saifuddin Azwar (dalam Agung, 2005:92) menyatakan bahwa dilihat dari wujud fisiknya, suatu tes tidak lain dari sekumpulan pertanyaan yang harus dijawab dan atau yang harus dikerjakan yang akan memberikan informasi mengenai aspek psikologis tertentu berdasarkan jawaban terhadap pertanyaan-pertanyaan atau cara dan hasil subjek dalam melakukan tugas-tugas tersebut. Instrumen yang digunakan untuk mengukur hasil belajar siswa adalah perangkat tes pilihan ganda.

Penelitian ini menggunakan analisis deskriptif kuantitatif. Analisis deskriptif kuantitatif adalah suatu cara pengolahan data yang dilakukan dengan jalan menyusun secara sistematis dalam bentuk angka-angka mengenai objek yang diteliti sehingga diperoleh kesimpulan umum (Agung, 2010:67). Metode analisis data yang digunakan untuk menganalisis data tentang hasil belajar dengan cara mengkonversikan persentase rata-rata kedalam tabel kriteria hasil belajar.

Adapun kriteria keberhasilan penilaian didalam penelitian tindakan kelas ini adalah dengan melihat hasil rekap nilai dari tes yang diberikan diakhir siklus. Penelitian tindakan kelas ini dikatakan berhasil apabila kriteria keberhasilan hasil belajar siswa mencapai di atas $80 \%$ dengan kategori tinggi demikian penelitian dapat diakhiri.

\section{HASIL DAN PEMBAHASAN}

Penelitian ini dilaksanakan dalam dua siklus. Data yang telah dikumpulkan dianalisis sesuai dengan metode analisis data yang telah ditetapkan sebelumnya. Adapun hasil dari analisis data mengenai data tentang hasil belajar IPA siswa terhadap pembelajaran yang dilaksanakan dijelaskan sebagai berikut.

Siklus I dilaksanakan dalam dua kali pertemuan untuk pelaksanaan tindakan dan satu kali pertemuan untuk melaksanakan tes hasil belajar IPA. Evaluasi hasil belajar IPA siswa menggunakan tes pilihan ganda yang terdiri atas 15 soal. Berdasarkan tes hasil belajar IPA siklus I diperoleh jumlah skor seluruh siswa sebesar 2661, sehingga rata-rata skor hasil belajar siswa (M) dan persentase tingkat hasil belajar (Mean $=70,2$ ) Hasil analisis persentase tingkat hasil belajar IPA siswa yang diperoleh selanjutnya dikonversasikan kedalam penilaian acuan patokan (PAP) skala lima. Berdasarkan perhitungan analisis data tingkat hasil belajar di atas pada siklus I mendapatkan hasil rata-rata 70,2 jika dikonversasikan ke dalam tabel PAP sekala lima maka hasil belajar pada siklus I berada dalam kategori sedang. Karena hasil analisis data siklus I belum mencapai indikator keberhasilan yang ditetapkan, maka dapat dikatakan bahwa hasil belajar IPA pada siswa kelas V SD N 4 Kaliuntu pada siklus I belum tuntas, sehingga perlu dilanjutkan ke siklus II.

Berdasarkan analisis data diatas, nilai rata-rata hasil belajar siswa pada siklus I yaitu 70,02 tergolong dalam kategori sedang. Walaupun demikian, hasil ini belum bisa mencapai kondisi ideal yaitu pencapaian nilai maksimum oleh siswa karena ada 9 siswa yang nilainya belum mencapai target KKM 65,00. Namun hal ini sudah menunjukkan adanya peningkatan setelah pelaksanaan pembelajaran dengan menggunakan model pembelajaran Group Investigation berbantuan video. Hal ini disebabkan oleh adanya beberapa kendala selama pembelajaran berlangsung.

Kendala-kendala yang ditemui selama proses pembelajaran dengan penerapan model pembelajaran Group Investigation berbantuan video adalah ada beberapa siswa yang tidak ikut terlibat dalam mencari jawaban sehingga pada saat mengerjakan evaluasi tidak bisa mengerjakan. Selain itu karena belum terbiasa dengan model pembelajaran ini siswa masih kebingungan dalam proses pelaksanaan investigasi. Untuk itu perlu dilanjutkan ke siklus II dengan melakukan beberapa penyempurnaan pembelajaran untuk mengatasi kendala yang ada pada siklus I.

Berdasarkan hasil penelitian siklus I, peneliti melakukan perbaikan terhadap kendalakendala pada penerapan model pembelajaran Group Investigation berbantuan video di pembelajaran siklus II. Pada pembelajaran siklus II, model yang diterapkan sama seperti siklus I yaitu model pembelajaran Group Investigation berbantuan video dengan beberapa perbaikan pada kendala yang dihadapi sebelumnya.

Rata-rata persentase hasil belajar siswa kelas V SD N 4 Kaliuntu pada siklus II adalah 80,07\% yang dikonversikan ke dalam PAP skala lima berada pada interval 80-89 dengan kriteria tinggi. 
Ketuntasan belajar (KB) pada siklus I diperoleh $84,21 \%$. Karena hasil analisis data siklus II sudah mencapai indikator keberhasilan yang ditetapkan, maka penelitian ini dapat dihentikan.

Pada pelaksanaan siklus II relatif permasalahan pada siklus I sudah diatasi. Selanjutnya hasil evaluasi siklus II dianalisis dan diperoleh nilai rata-rata pada siklus II yaitu 80,07 \% tergolong dalam kategori tinggi dan kriteria keberhasilan juga menunjukkan kategori tinggi yaitu mencapai $84,21 \%$, sehingga penelitian ini dirasakan cukup dan penelitian ini dapat dihentikan. Untuk mempermudah melihat peningkatan hasil belajar siswa dapat dilihat pada tabel berikut.

Tabel 4.3 Data peningkatan Hasil Belajar IPA siklus I dan Siklus II

\begin{tabular}{cccc}
\hline Variabel & Siklus I & Siklus II & Peningkatan \\
\hline Mean & $70,02 \%$ & $80,07 \%$ & $10,5 \%$ \\
Ketuntasan Belajar & $76,31 \%$ & $84,21 \%$ & $7,89 \%$ \\
\hline
\end{tabular}

Penerapan model pembelajaran Group Investigation berbantuan video di SD N 4 Kaliuntu yang diterapkan pada siswa kelas $\mathrm{V}$ berjumlah 38 siswa sudah berjalan dengan baik dan sesuai dengan yang direncanakan yaitu untuk meningkatkan hasil belajar IPA siswa. Penelitian ini dilakukan dalam dua siklus. Tiap siklus terdiri dari dua petemuan.

Secara umum penelitian yang telah dilakukan sudah dikatakan berhasil dan sudah memenuhi kriteria yang ditetapkan. Namun, pelaksanan tindakan pada siklus I belum dapat mencapai hasil yang optimal dan belum memenuhi kriteria keberhasilan yang ditetapkan. Pada siklus I, rata-rata hasil belajar IPA yang diperoleh, 70,02, bila dikonversikan ke dalam tabel Penilaian Acuan Patokan (PAP) berada pada interval 65-79 yaitu kriteria sedang. Selain itu, ketuntasan belajar siswa masih belum sesuai dengan yang diharapkan yaitu hanya $76,31 \%$. Sehingga indikator keberhasilan belum tercapai yakni minimal $80 \%$. Hal ini disebabkan karena ada beberapa kendala yang dihadapi pada siklus I.

Berdasarkan kekurangan yang ada pada siklus I yaitu persiapan pembelajaran yang masih kurang, masih banyak siswa yang belum aktif dalam mengerjakan tugas, siswa belum terbiasa belajar menggunakan model pembelajaran Group Investigation berbantuan video dan belum mampu mengkoordinasikan kelompok dengan baik, terbukti kelompok hanya mengandalkan siswa yang dianggap pandai untuk megerjakan tugas, maka pelaksanaan tindakan pada siklus II diupayakan lebih baik lagi. Sehingga diperoleh hasil tes siswa mengalami peningkatan. Rata-rata hasil belajar IPA siswa pada siklus II sebesar 80,07 bila dikonversikan berada pada interval 80-89 yaitu pada kriteria “tinggi". Dengan ketuntasan belajar yang dimiliki 84,21\%. Dari data menunjukkan 32 dari 38 siswa sudah termasuk dalam kategori tuntas dan sudah memenuhi target yang ditentukan yaitu minimal $80 \%$ maka penelitian ini sudah mencapai kategori keberhasilan. Peningkatan pada siklus II disebabkan karena kemauan dan keinginan siswa untuk memperoleh nilai yang lebih optimal dan juga penerapan model pembelajatan Group Investigation berbantuan video memberikan kemajuan yang positif untuk peningkatan keberhasilan proses pembelajaran untuk mencapai tujuan pendidikan yang baik.

Model pembelajaran Group Investigation merupakan salah satu model pembelajaran yang sesuai dengan pendekatan statisfik dalam pembelajaran kurikulum 2013. Menurut Trianto (2009:166) menyatakan bahwa, 'model pembelajaran Group Investigation berarti suatu rangkaian kegiatan belajar yang melibatkan secara maksimal seluruh kemampuan peserta didik untuk mencari dan menyelidiki secara sistematis, kritis, logis, analitis sehingga mereka dapa merumuskan sendiri penemuannya dengan penuh percaya diri. Siswa dilatih untuk menumbuhkan kemampuan berpikir mandiri, analitis, kritis, kreatif, reflektif, dan produktif'. Selain itu, dengan adanya pembentukan kelompok, siswa dapat mengembangkan sikap saling memahami dan demokrasi, sikap kerjasama dengan teman sekelompok, serta komunikasi yang baik antar anggota kelompok. Dengan dibentuknya kelompok ini, siswa menjadi lebih aktif dalam pembelajaran. Interaksi dengan guru juga menjadi lebih baik, dengan guru berkeliling dan membimbing setiap kelompok. Selain itu penggunaan media video juga merupakan alternatif yang baik dalam pembelajaran.

Karena dengan video, guru dapat menyampaikan pesan kepada siswa. Dalam video, siswa dapat melihat gambar sekaligus suara yang menyertainya. Dengan berfungsinya kedua indra yaitu indra penglihatan dan indra pendengaran, maka siswa akan dapat lebih mengingat apa yang ada dalam video tersebut, sehingga penyampaian pesan dalam video itu akan terjadi secara maksimal. Model pembelajaran Group Investigation berbantuan video dapat meningkatkan keterampilan guru dalam mengajar, guru jadi lebih mudah menyampaikan materi dengan adanya bantuan media video. Siswa juga menjadi lebih aktif 
dan tertarik dalam pembelajaran. Dengan adanya diskusi kelompok, siswa dituntut untuk bekerja secara maksimal. Sehingga hasil belajar siswa dalam penggunaan model pembelajaran Group Investigation berbantuan video pada pembelajaran IPA ini dapat meningkat dan kualitas pembelajaran pun akan meningkat secara keseluruhan. Penelitian ini juga berhasil karena didukung oleh hasil penelitian temuan peneliti sebelumnya yang sudah dipaparkan dalam kajian penelitian yang relevan dengan penelitian ini.

Berdasarkan analisis tersebut dapat disimpulkan bahwa model pembelajaran Group Investigation berbantuan video dapat meningkatkan hasil belajar IPA siswa kelas V SD N 4 Kaliuntu.

\section{KESIMPULAN DAN SARAN}

Berdasarkan hasil penelitian dan pembahasan yang telah diuraikan, dapat disimpulkan bahwa pembelajaran IPA melalui model pembelajaran Group Investigation berbantuan video dapat meningkatkan hasil belajar siswa, ditunjukkan dengan data hasil belajar siswa meningkat $10,5 \%$ pada siklus I dengan rata-rata $70,02 \%$ sedangkan pada siklus II rata-rata $80,07 \%$. Sedangkan ketuntasan belajar siswa meningkat 7,89\% dari 76,31 pada siklus I menjadi $84,21 \%$ pada siklus Jadi dapat disimpulkan penerapan model pembelajaran Group Investigation berbantuan video dapat meningkatkan hasil belajar IPA siswa kelas V SDN 4 Kaliuntu.

\section{DAFTAR PUSTAKA}

Agung, A. A. G. 2005. Metodologi Penelitian Pendidikan.

Singaraja: Fakultas Ilmu Pendidikan Institut Keguruan dan Keilmuan Negeri Singaraja.

2010. Metodologi Penelitian Pendidikan. Singaraja: FIP Undiksha.

Ahmadi dan Supriyono. 2004. Psikologi Belajar. Jakarta: Rineka Cipta

Ahmadi, dkk., 2005. Strategi Belajar Mengajar. Bandung: CV. Pustaka Setia

Arikunto. 2006. Modellogi penelitian, Yogyakarta: Bina Aksara.

Asma, Nur. 2006. Model PembelajaranKooperatif.Jakarta: Departemen Pendidikan Nasional

Direktorat Jenderal Pendidikan Tinggi Direktorat Ketenagaan

Astriany, N. 2012. Meningkatkan Hasil Belajar IPA Melalui Penggunaan Mind Mapping Siswa Kelas IV Sekolah DasarBekasi Utara. Jurnal Pendidikan Dasar

Dewiki dan Yuniati. 2006. Ilmu Alamiah Dasar. Jakarta : Universitas Terbuka di akses tanggal pada tanggal 26 juli 2017

Fathurrohman. 2007. Strategi Belajar Mengajar. Bandung : PT Refika Aditama

Ferdausy, Priharini. 2012. Peningkatan Kualitas Pembelajaran IPS melalui Model Role Playing dengan Media Video Pembelajaran pada Siswa Kelas III SD Negeri

Petompon 01 Semarang. Skripsi, Jurusan Pendidikan Guru Sekolah Dasar Universitas Negeri Semarang.

Hamalik, Oemar. 2011. Perencanaan Pengajaran berdasarkan Pendekatan Sistem. Jakarta: Bumi Aksara

Hamdani. 2011. Strategi Belajar Mengajar. Bandung: Pustaka Setia

Huda, Miftahul. 2013. Model-model Pengajaran dan Pembelajaran. Pustaka Pelajar. Malang

Kusnandar. 2010. Guru Profesional Implementasi kurikulum Tingkat satuan Pendidikan (KTSP) dan Sukses Dalam Sertifikasi Guru. Jakarta: Rajawali Pers 
Peraturan Menteri Pendidikan Nasional Nomor 22 Tahun 2006.

Prastowo, Andi. 2012. Panduan Kreatif Membuat Bahan Ajar Inovatif. Jogjakarta: Diva Press. Pusat Pembinaan dan Departemen

Pendidikan Nasional. (2001). Kamus Besar Bahasa Indonesia. Jakarta: Balai Pustaka.

Rustaman, Nuryani, dkk. 2011. Materi dan Pembelajaran IPA SD. Jakarta: Universitas Terbuka

Sukiman. 2012. Pengembangan Media Pembelajaran. Yogyakarta: Pedagogia. 